\title{
PRESENT TRENDS IN RESEARCH ON APPLICATION OF ARTIFICIAL NEURAL NETWORKS IN AGRICULTURAL ENGINEERING ${ }^{1}$
}

\author{
Sławomir Francik ${ }^{*}$, Zbigniew Ślipek, Jarosław Frączek, Adrian Knapczyk
}

Department of Mechanical Engineering and Agrophysics, University of Agriculture in Krakow

*Corresponding author: e-mail: slawomir.francik@ur.krakow.pl

ARTICLE INFO

Article history:

Received: September 2016

Received in the revised form

October 2016

Accepted: November 2016

Key words:

agricultural engineering,

artificial neural network,

bibliometric analysis,

dynamics of publishing

\begin{abstract}
The objective of the paper was to carry out a bibliometric quantitative analysis of publications concerning the application of artificial neural networks in the research area - agriculture and a bibliometric quantitative analysis and subject analysis with regard to agricultural engineering. A number of scientific publications devoted to the ANN found in the data base of the Web of Science - in documents published to 2015 was a basis for the quantitative analysis. Research on the use of artificial neural networks in the research area agriculture is extending systematically. Moreover, a rapidly growing number of citations prove a continuous increase in the scientists' interest in possibilities of the ANN applications. The quantitative analysis of scientific publications in 5 selected scientific journals and thematically related to agricultural engineering (indexed in the Web of Science) allowed a statement that 236 scientific articles from 19962015 were related to the ANN application. The biggest number of publications was reported in Computers and Electronics in Agriculture - 118 articles. In 2011-2015 there was a growing trend in dynamics of publishing of scientific papers devoted to the ANN application to agricultural engineering. Thus, we may assume that the research related to application of the artificial neural networks to agricultural engineering will be continued and their scope and number will be still growing. The thematic analysis of the most often quoted publications from 2011-2015 in the journal Computers and Electronics in Agriculture, proved that they concern both the issues related to the classification problem as well as to modelling processes and systems. We should suppose that the subjects related to modelling of drying processes and application of neural networks for image analysis will grow dynamically in the following years.
\end{abstract}

1 This Research was funded by the Ministry of Science and Higher Education of the Republic of Poland 


\section{Introduction}

In the recent years in various fields of science artificial intelligence methods are used more often. Computational Intelligence - CI which is a part of Artificial Intelligence - AI was defined, inter alia, by Bezdeka (1994 after Jain et al., 2008). He claimed that „... a system is computationally intelligent when it: deals only with numerical (low-level) data, has a pattern recognition component, and does not use knowledge in the AI sense; and additionally when it (begins to) exhibit (i) computational adaptivity; (ii) computational fault tolerance; (iii) speed approaching human-like turnaround, and (iv) error rates that approximate human performance...”. Artificial Neural Networks -ANN are one of five main fields of CI (Engelbrecht, 2007):

- Artificial Neural Networks (ANN),

- Evolutionary Computation (EC),

- Swarm Intelligence (SI),

- Artificial Immune Systems(AIS),

- Fuzzy Systems (FS).

Artificial Neural Networks are inspired by operation of biological neural networks a brain. The beginning of ANN development is assumed to fall on development of a mathematical model of neurone by McCulloch and Pitt in 1943 and introduction of the concept of adaptation of connections between network nodes in the process of learning neural networks by Hebb (1949) (Jain et al., 2008). There were some milestones in the development of research on the ANN. They consisted in the first program simulation of the ANN by Rochester (1956), creation of the first neurocomputer (Perceptron-1958) by Rosenblatt and Wightman. After the periods of initial development and the so-called golden era of the ANN there was a period of regression in this research (1970-1982). It resulted from the publishing of Minsky's and Papert's book titled „Perceptrons” (1969), where they described significant limitations of neural networks. In 1986 a study by McClelland and Rumelhart titled „Parallel Distributed Processing” appeared which has opened a new era of sudden development of research concerning the ANN and their even wider application. Presently, there is no scientific field where the ANN was not used (Hagan et al., 2014; Kasabov, 1998; Zurada, 1992).

\section{The objective, scope and methods}

The objective of the paper was to carry out a bibliometric quantitative analysis of publications concerning the application of the artificial neural networks in the research area - agriculture and bibliometric quantitative analysis and thematic analysis in agricultural engineering.

A number of scientific articles devoted to the ANN found in the data base of the Web of Science - in documents published to 2015 was a basis for the bibliometric quantitative analysis. An assumption was made that the number of publications in reputed scientific journals may prove significance of a given scientific issue. These journals have the Impact Factor assigned by JCR and are indexed in the Web of Science. 
Present trends in research...

Research task 1 - the bibliometric quantitative analysis of a publication in the research area of agriculture

The task aimed at the determination of the trend concerning changes in the number of scientific publications in the research area - agriculture devoted to the artificial neural networks. As a part of the task a search in the WoS was carried out - criteria of searching:

- subject: artificial neural network,

- document types: article,

- research domains: science technology,

- research areas: agriculture.

Selection of the "subject" criterion causes that articles with key words in the title, abstract and key words are searched in the Web of Science. Therefore, it is the most complete search of the base.

Research task 2 - the bibliometric quantitative analysis of a publication in the research area of agricultural engineering

The task aimed at determination of short-period trends concerning application of the ANN in the agricultural engineering discipline based on the number of articles published to 2015 in the selected journals.

A journal for analysis was selected based on the analysis of scientific articles published to 2015 in the journals from the research areas - agriculture qualified to the category Web of Science: (WoS Categories: Agricultural Engineering, Agriculture Multidisciplinary). In further analyses only the most important journals were included (those belonging to Q1 or Q2 in given the WoS categories), whose basic subject field concerned a discipline of agricultural engineering and where totally 10 publications were published. These were:

- Computers and Electronics in Agriculture (COMPUT ELECTRON AGR): 118 publications, Q1

- Biosystems Engineering (BIOSYST ENG): 44 publications, Q2

- Bioresource Technology (BIORESOURCE TECHNOL): 37 publications, Q1

- Journal of Agricultural Science and Technology (J AGRIC SCI TECHNOL): 21 publications, Q2

- Industrial Crops and Products (IND CROP PROD): 17 publications, Q1

When the journals were selected analysis of the number of articles published in particular years was carried out.

Research task 3 - the bibliometric quantitative analysis of a publication in the research area of agricultural engineering

As a part of the task, analysis of the research subject in five most often quoted scientific articles published in Computers and Electronics in Agriculture was carried out. An assumption was made that citations reflect the interest of the scientific environment with a given subject and thus it will develop the most intensely in a short time. Selection to Computers and Electronics in Agriculture resulted from the fact that this journal published the biggest number of articles devoted to the ANN. 


\section{Results and discussion}

As a result of searching in the Web of Science base for the concept „Artificial Neural Network” in the research area: agriculture, to 20151164 scientific publications devoted to neural networks were found (Research task 1). Among the found publications, Polish scientists were co-authors of 20 articles (the first publications from 2003). The oldest publications in the research area: agriculture come from 1991 (Fig. 1). In the following years the number of publications increased. In 2015 this number was 138 publications.

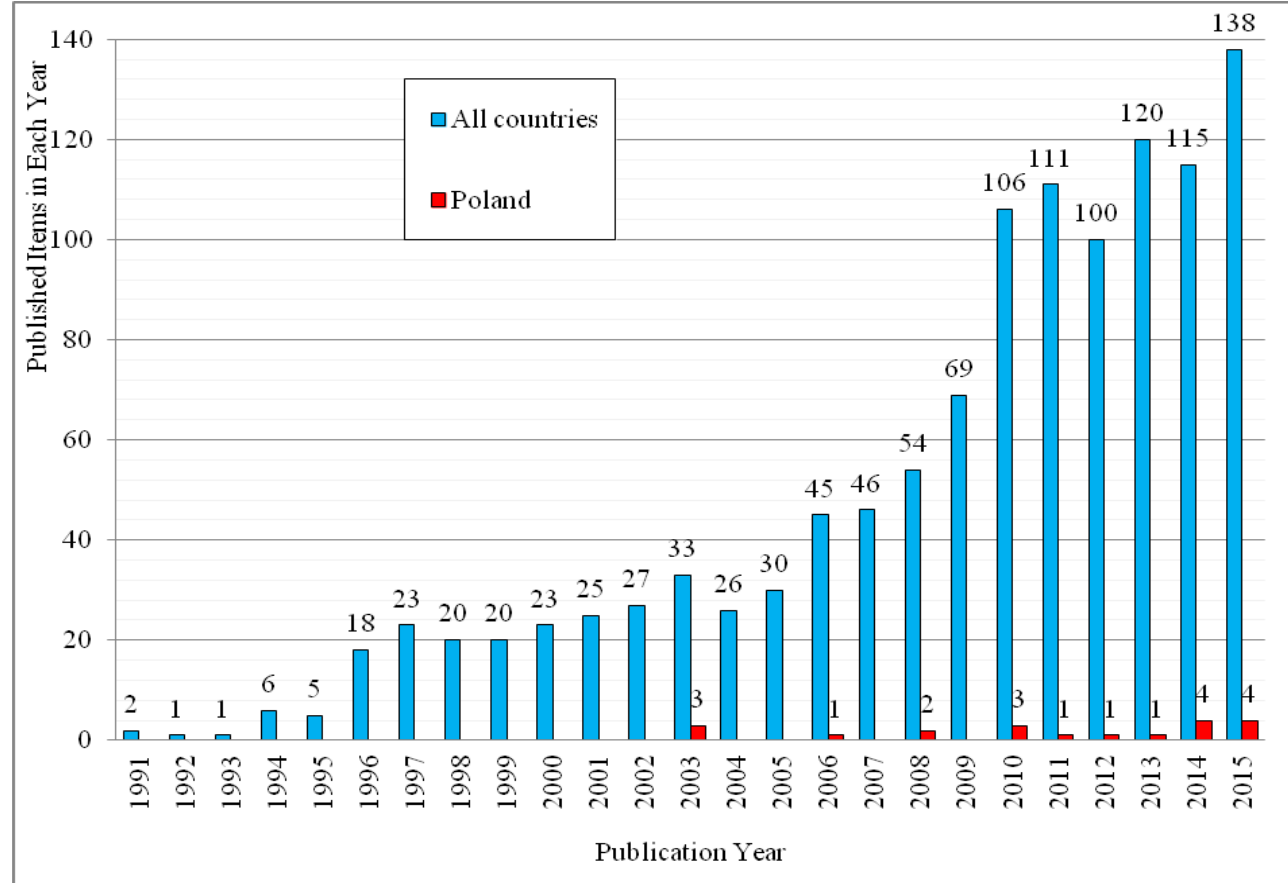

Figure 1. Number of publications concerning ANN applications in the agricultural sciences field

Polish scientists (affiliation in the Polish scientific institution placed first publications on the ANN application in the research area: agriculture only in 2003 (12-year delay) - it results from a long period of isolation and difficult access to journals with an international reputation.

Analysis of the number of publications in particular years allows distinguishing several periods:

- the first one: 1991-1995 - average annual number of publications (AANP) is 3.0 scientific articles,

- the second one: 1996-2005: - AANP = 24.5 article,

- third: 2006-2009 - AANP = 53.5 articles

- fourth: 2010-2015 - AANP = 115.0 article 
Present trends in research...

Thus, in 2010 there was a sudden growth in the number of publications on the ANN in the research area: agriculture. It results from the increase in the interest of scientists with the use of CI tools. Also, the number of citations of publications, which increases exponentially, proves the above (Fig. 2). It exceeded 1100 citations in 2010 and 2200 citations in 2015. In 1993-2016 the total number of citations of all searched publications was 14230, including publications of the Polish authors 163 (1.1\%).

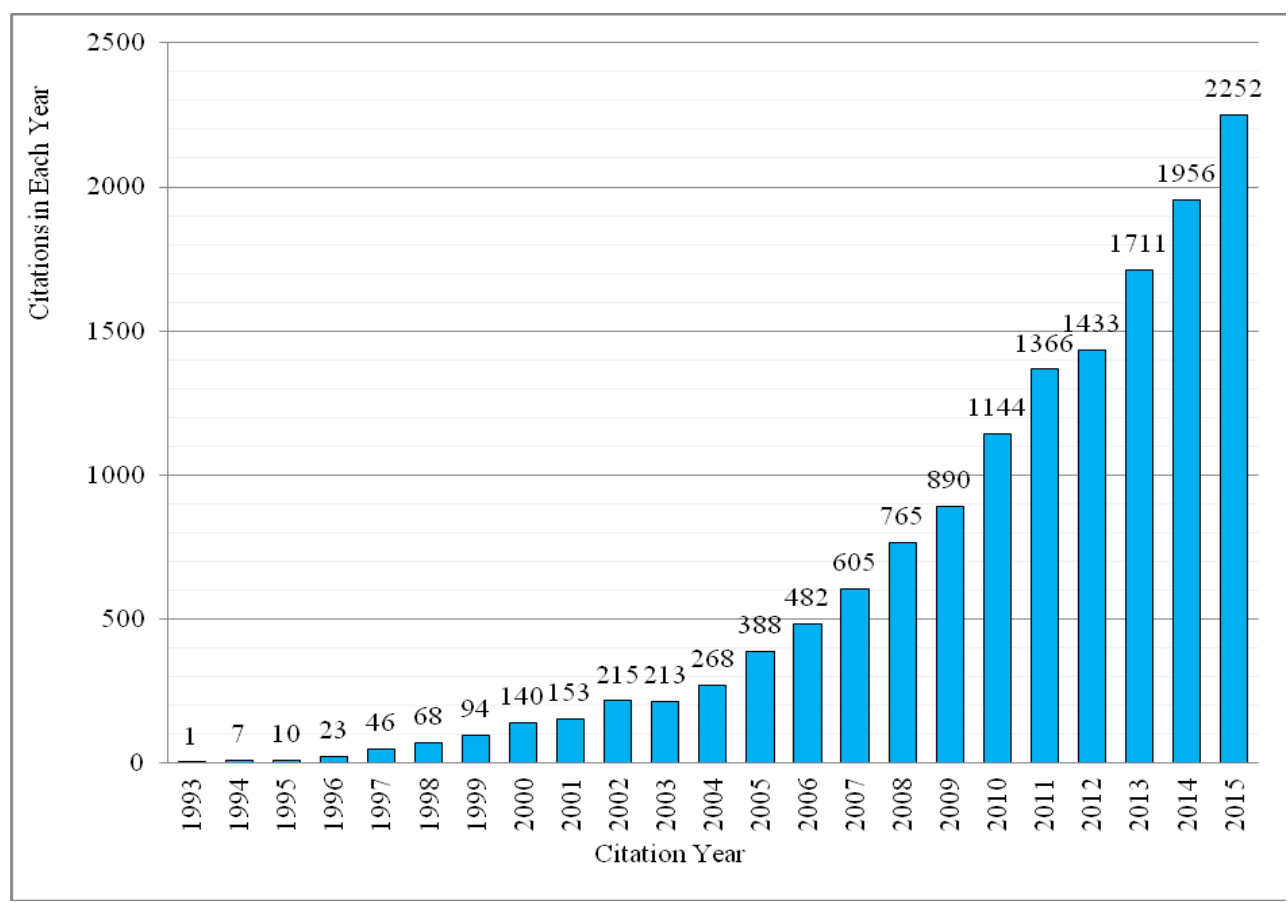

Figure 2. Number of citations in publications concerning ANN applications in the research area- agriculture

Searching the Web of Science base (Research task 2) allowed identification of 236 articles devoted to the ANN application in the discipline: agricultural engineering (in five selected journals) published to 2015. The biggest number of articles was found in the journal titled Computers and Electronics in Agriculture - in total 118 publications from 1996-2015. 


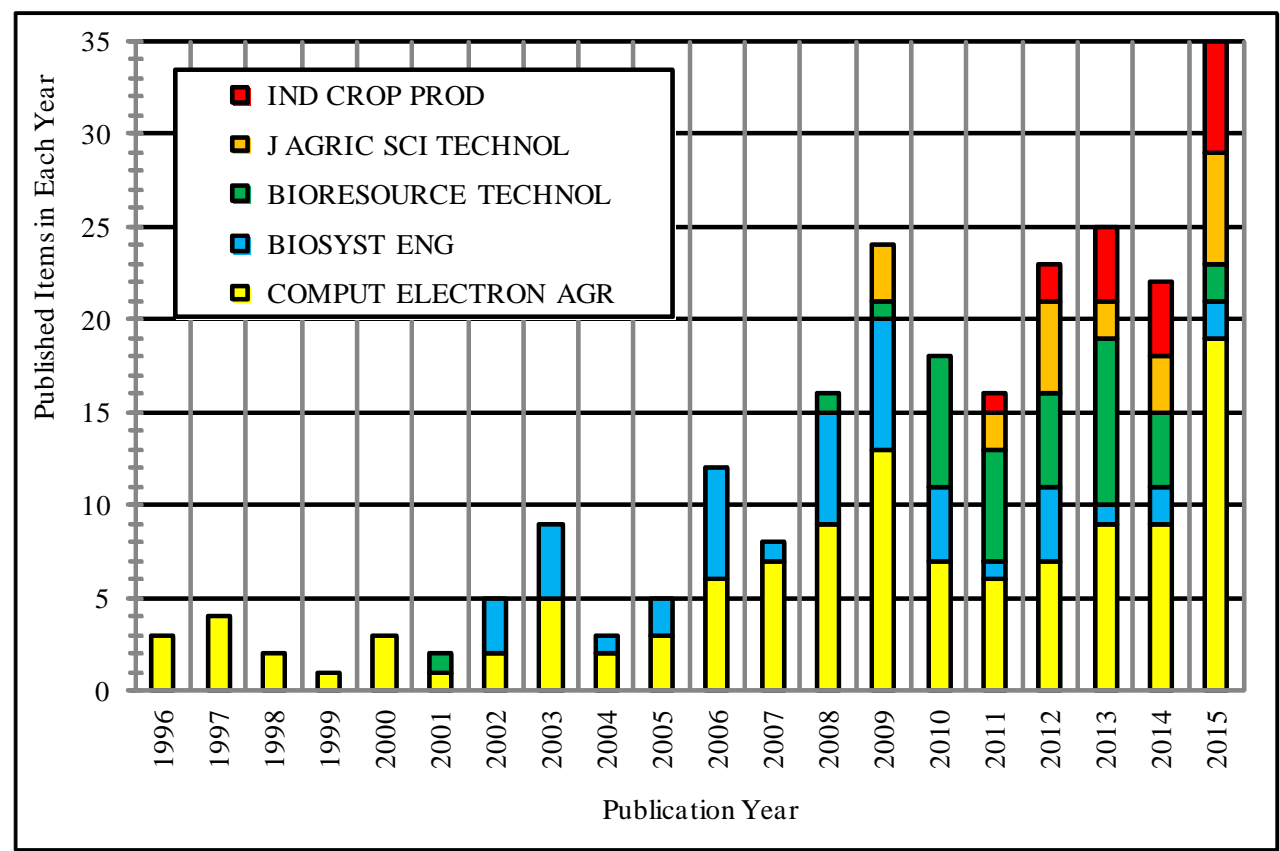

Figure 3. Number of articles published to 2015 concerning application of artificial neural networks in discipline:agricultural engineering

Analysis of the number of publications in particular years allows distinguishing several periods (Fig. 3):

- 1996-2005: - AANP = 3.7 scientific article,

- 2006-2010 - AANP $=15.6$ articles

- 2011-2015 - AANP $=24.2$ article

It should be emphasised that in the last period there was a clear growing trend and articles devoted to the ANN applications were published every year in all five journals. In 2011 a new publication appeared which concerned application of the artificial neural networks in the journal IND, CROP, PROD. It may be stated that to 2011 there was another increase in the scientists' interest in application of the ANN (after a short period of interest drop in 2010-2011). Thus, in 2011-2015 there is a growing trend in dynamics of publication of scientific papers devoted to ANN application in agricultural engineering. Therefore, further analyses were carried out for this period with reference to journals were the biggest number of articles was published - Computers and Electronics in Agriculture.

Identification of countries, from which scientists come from (affiliation in Polish scientific units) who carry out research on the ANN application (publications from 20112015) in the journal Computers and Electrnics in Agriculture) proved that majority of authors of this type of articles were scientists from Iran (14 publications). Further position was taken by Turkey (6 publications), Spain (5 publications), Brazil, China, Serbia (4 publications each) and Thailand (3 publications). There were only 2 publications of 
Present trends in research...

the Polish authors (Boniecki et al., 2015; Szczypiński et al. 2015). Authors from England, India, Malesia, Taiwan and USA published two articles each.

In 2011-2015 in Computers and Electronics in Agriculture the biggest number of articles (3 each) was published by:

- Milan GOCIC from Serbia (Univ Nis, Fac Civil Engn \& Architecture, Nish): (Gocic et al., 2015; Gocic and Trajkovic, 2011; Mohammadi et al., 2015),

- Ozgur KISI z Turkey (Canik Basari Univ, Dept Civil Engn, Fac Engn \& Architecture, Samsun): (Cobaner et al., 2014; Kisi et al., 2015; Shiri et al,. 2014),

- Pau MARTI from Spain (Univ Politecn Valencia, Dept Engn Rural \& Agroalimenteria, Valencia): (Shiri et al., 2014; Marti et al., 2013a; Marti et al., 2013b),

- Mahmoud OMID from Iran (Univ Tehran, Dept Agr Machinery Engn, Fac Agr Engn \& Technol, Karaj): (Mollazade et al., 2012; Teimouri et al., 2014; Nourbakhsh et al., 2014).

The increase in the interest in the analysed scientific subjects results not only in the growth of the number of publications but also in the increase in the number of citations of articles on these subjects (Research task 3).

The number of citations of articles published in 2011-2015 in Computers and Electornics in Agriculture increased suddenly - from 2 citations in 2011 to 93 citations in 2015 (Fig. 4).

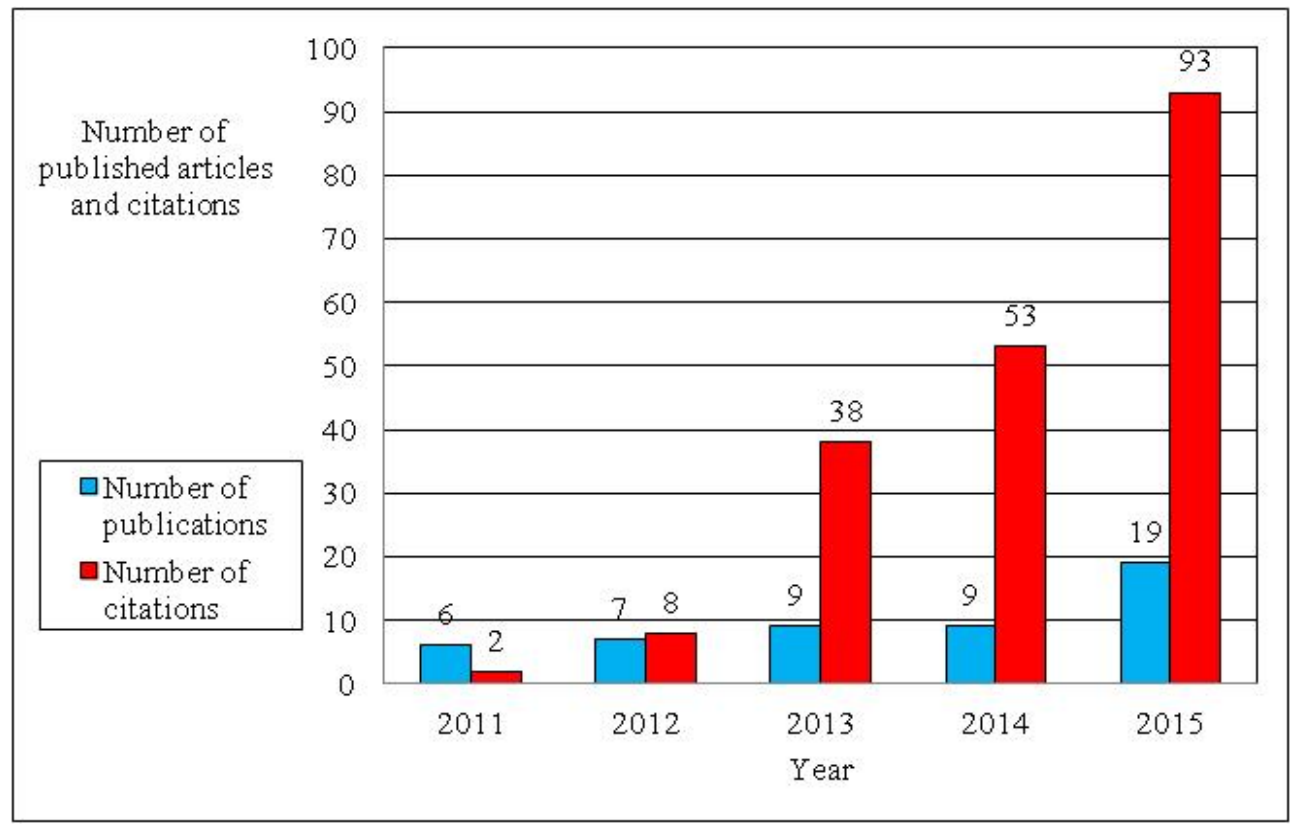

Figure 4. Number of articles published in 2011-2015 in Computer and Electronics in Agriculture and number of their citations

The most often cited scientific papers published in the journal titled Computers and Electronics in Agriculture in 2011-2015 were presented in Table 1. Based on them the 
S. Francik, Z. Ślipek, J. Frączek, A. Knapczyk

research subjects related to the ANN application were determined, which focus the most the scientists' interest.

Table 1.

Most often cited scientific papers published in Computers and Electronics in Agriculture in 2011-2015

\begin{tabular}{|c|c|c|}
\hline $\begin{array}{l}\text { Year } \\
\text { of } \\
\text { publication }\end{array}$ & Publication & $\begin{array}{cc}\text { Number } & \text { Average } \\
\text { of } & \text { number of } \\
\text { quotatio } & \text { quotations } \\
\text { ns } & \text { quan }\end{array}$ \\
\hline
\end{tabular}

\begin{tabular}{|c|c|c|c|}
\hline 2011 & $\begin{array}{l}\text { Nazghelichi, T., Aghbashlo, M., Kianmehr, M.H., (2011). } \\
\text { Optimization of an artificial neural network topology using } \\
\text { coupled response surface methodology and genetic algorithm for } \\
\text { fluidized bed drying. Computers and Electronics in Agriculture. } \\
\text { Vol. 75, Issue 1, 84-91. }\end{array}$ & 24 & 4.8 \\
\hline 2012 & $\begin{array}{l}\text { Mollazade, K., Omid, M., Arefi, A. (2012). Comparing data } \\
\text { mining classifiers for grading raisins based on visual features. } \\
\text { COMPUTERS AND Computers and Electronics in Agriculture. } \\
\text { Vol. 84, 124-131. }\end{array}$ & 20 & 5.0 \\
\hline 2012 & $\begin{array}{l}\text { Nadimi, E.S.; Jorgensen, R.N.; Blanes-Vidal, V.; Christensen, S. } \\
\text { (2012). Monitoring and classifying animal behaviour using } \\
\text { ZigBee-based mobile ad hoc wireless sensor networks and } \\
\text { artificial neural networks. Computers and Electronics in } \\
\text { Agriculture. Vol. 82, 44-54. }\end{array}$ & 14 & 3.5 \\
\hline 2012 & $\begin{array}{l}\text { Aghbashlo, M., Mobli, H., Rafiee, S., Madadlou, A. (2012). The } \\
\text { use of artificial neural network to predict exergetic performance } \\
\text { of spray drying process: A preliminary study. Computers and } \\
\text { Electronics in Agriculture. Vol. 88, 32-43. }\end{array}$ & 13 & 3.3 \\
\hline 2011 & $\begin{array}{l}\text { Hendrawan, Y., Murase, H. (2011). Neural-Intelligent Water } \\
\text { Drops algorithm to select relevant textural features for developing } \\
\text { precision irrigation system using machine vision. Computers and } \\
\text { Electronics in Agriculture. Vol. 77, Issue 2, 214-228. }\end{array}$ & 11 & 2.2 \\
\hline
\end{tabular}

Source: author's own study based on the Web of Science

Publications concerning modelling of drying processes were the most often quoted (Table 1). Neurone models which enable determination of energy and exergy (ANN output) were crated during drying of carrot dice in the fluid bed (Nazghelichi et al., 2011) and spray drying of emulsion - fish oil and skimmed powder milk (Aghbashlo et al., 2012). Interest in modelling of drying processes with the use of the ANN indicates that this subject will be developing in the following years.

Also, papers devoted to issues of classification with the use of the ANN were often quoted (Table 1). Artificial Neural Networks were, inter alia, used for classification of raisins based on their colour (Mollazade et al., 2012) and classification of sheep behaviour (Nadimi et al., 2012). 
Present trends in research...

Scientists were also very interested in the publication concerning application of the ANN as an element of the precise hydration system Hendrawan and Murase, 2011).

\section{Summary and conclusions}

Research on the application of artificial neural networks in the research area agriculture is extending systematically. Since 1991 (the first publication indexed in the Web of Science), the number of publications resulting from the number of scientific research, which was carried out, still grows. Since 2006, the number of publications quoted in the Web of Science base, started to grow very rapidly by the sudden change, which took place in 2010 (the number of publications - over 100). Furthermore, a rapidly growing number of citations prove the increase in the scientists' interest in the possibilities of the ANN application in the research area - agriculture (2010 - over 1100 citations, 2015 - 2200 citations). Thus, it may be stated that the interest of scientists in the application of artificial neural networks for various tasks in the research area - agriculture constantly grows.

Also, in the discipline - agricultural engineering numerous research related to the application of artificial neural networks were carried out and covered various problems. The quantitative analysis of scientific publications in 5 selected scientific journals related to agricultural engineering with regard to the subject (indexed in the Web of Science base) allowed determination that 236 scientific articles from 1996-2015 were related to the ANN application but in 2011-2015 there was a growing trend of the dynamics of the published scientific papers devoted to the ANN application in agricultural engineering. Thus, we may assume that the research related to application of the artificial neural networks in agricultural engineering will be continued and their scope and number will be still growing.

The biggest number of publications appeared in Computers and Electronics in Agriculture (totaly 118 publications in 1996-2015). Thus, further detailed analyses were carried out for the period of 2011-2015 and for the journal Computers and Electronics in Agriculture. Scientists from Iran (14), Turkey (6) and Spain (5) were the authors of the biggest number of publications. Analysis of subjects of the most often quoted publications from 2011-2015 in the journal Computers and Electronics in Agriculture, proved that they concern both the issues related to the problem of classification (classification of raisins, classification of sheep behaviour) as well as modelling processes (drying process) and biotechnical systems (a precise hydration system). The ANNs are mainly used for connecting prediction problems. We may notice a trend in the use of artificial neural networks for analysis of the image. Investigations concerning modelling of the drying process, in particular with regard to exergy analysis are significant.

Thus, one should claim, that application of artificial neural networks for modelling various types of processes (in particular drying processes) and for classification (in particular based on the image analysis) will be in the future a subject of the majority of papers concerning ANN in the agricultural engineering discipline. 
S. Francik, Z. Ślipek, J. Frączek, A. Knapczyk

\section{References}

Aghbashlo, M., Mobli, H., Rafiee, S., Madadlou, A. (2012). The use of artificial neural network to predict exergetic performance of spray drying process: A preliminary study. Computers and Electronics in Agriculture, 88, 32-43.

Boniecki, P., Koszela, K., Piekarska-Boniecka, H., Weres, J., Zaborowicz, M., Kujawa, S., Majewski, A., Raba, B. (2015). Neural identification of selected apple pests. Computers and Electronics in Agriculture, 110, 9-16.

Cobaner, M., Citakoglu, H., Kisi, O., Haktanir, T. (2014). Estimation of mean monthly air temperatures in Turkey. Computers and Electronics in Agriculture, 109, 71-79.

Engelbrecht A.P. (2007). Computational Intelligence. An Introduction. 2nd ed.. John Wiley \& Sons Ltd. ISBN 978-0-470-03561-0.

Gocic, M., Motamedi, S., Shamshirband, S., Petkovic, D., Sudheer, C., Hashim, R., Arif, M. (2015). Soft computing approaches for forecasting reference evapotranspiration. Computers and Electronics in Agriculture, 113, 164-173.

Gocic, M., Trajkovic, S. (2011). Service-oriented approach for modeling and estimating reference evapotranspiration. Computers and Electronics in Agriculture, 79, 153-158.

Hagan M.T., Demuth H.B., Beale M.H., De Jesus O. (2014). Neural Network Design (2nd Edition). Martin Hagan. ISBN-10: 0-9717321-1-6. ISBN-13: 978-0-9717321-1-7.

Hendrawan, Y., Murase, H. (2011). Neural-Intelligent Water Drops algorithm to select relevant textural features for developing precision irrigation system using machine vision. Computers and Electronics in Agriculture, 77, 214-228.

Jain, L.C., Tan S.C., Lim. C.P. (2008). An Introduction to Computational Intelligence Paradigms. Studies in Computational Intelligence, 137, 1-23.

Kasabov, N.K. (1998). Foundations of neural networks, fuzzy systems, and knowledge engineering. Cambridge, Mass. MIT Press. ISBN 0-262-11212-4.

Kisi, O., Sanikhani, H., Zounemat-Kermani, M., Niazi, F. (2015). Long-term monthly evapotranspiration modeling by several data-driven methods without climatic data. Computers and Electronics in Agriculture, 115, 66-77.

Marti, P., Shiri, J., Duran-Ros, M., Arbat, G., de Cartagena, F.R., Puig-Bargues, J. (2013a). Artificial neural networks vs. Gene Expression Programming for estimating outlet dissolved oxygen in micro-irrigation sand filters fed with effluents. Computers and Electronics in Agriculture, 99, 176-185.

Marti, P., Gasque, M., Gonzalez-Altozano, P. (2013b). An artificial neural network approach to the estimation of stem water potential from frequency domain reflectometry soil moisture measurements and meteorological data. Computers and Electronics in Agriculture, 91, 75-86.

Mohammadi, K., Shamshirband, S., Motamedi, S., Petkovic, D., Hashim, R., Gocic, M. (2015). Extreme learning machine based prediction of daily dew point temperature. Computers and Electronics in Agriculture, 117, 214-225.

Mollazade, K., Omid, M., Arefi, A. (2012). Comparing data mining classifiers for grading raisins based on visual features. Computers and Electronics in Agriculture, 84, 124-131.

Nadimi, E.S., Jorgensen, R.N., Blanes-Vidal, V., Christensen, S. (2012). Monitoring and classifying animal behaviour using ZigBee-based mobile ad hoc wireless sensor networks and artificial neural networks. Computers and Electronics in Agriculture, 82, 44-54.

Nazghelichi, T., Aghbashlo, M., Kianmehr, M.H., (2011). Optimization of an artificial neural network topology using coupled response surface methodology and genetic algorithm for fluidized bed drying. Computers and Electronics in Agriculture, 75, 84-91.

Nourbakhsh, H., Emam-Djomeh, Z., Omid, M., Mirsaeedghazi, H., Moini, S. (2014). Prediction of red plum juice permeate flux during membrane processing with ANN optimized using RSM. Computers and Electronics in Agriculture, 102, 1-9. 
Present trends in research...

Shiri, J., Nazemi, A.H., Sadraddini, A.A., Landeras, G., Kisi, O., Fard, A.F., Marti, P. (2014). Comparison of heuristic and empirical approaches for estimating reference evapotranspiration from limited inputs in Iran. Computers and Electronics in Agriculture, 108, 230-241.

Szczypinski, P.M., Klepaczko, A., Zapotoczny, P. (2015) Identifying barley varieties by computer vision. Computers and Electronics in Agriculture, 110, 1-8.

Teimouri, N., Omid, M., Mollazade, K., Rajabipour, A. (2014). A novel artificial neural networks assisted segmentation algorithm for discriminating almond nut and shell from background and shadow. Computers and Electronics in Agriculture, 105, 34-43.

Zurada J.M. (1992). Introduction to Artificial Neural Systems. West Publishing Co. St. Paul, MN, USA. ISBN 0-3 14-93391 -3.

\section{AKTUALNE KIERUNKI BADAŃ DOTYCZĄCYCH ZASTOSOWAŃ SZTUCZNYCH SIECI NEURONOWYCH W INŻYNIERII ROLNICZEJ}

Streszczenie. Celem pracy było przeprowadzenie bibliometrycznej analizy ilościowej publikacji dotyczących wykorzystania sztucznych sieci neuronowych (ANN) w obszarze badawczym rolnictwo oraz bibliometrycznej analizy ilościowej i tematycznej w dyscyplinie inżynieria rolnicza. Podstawą dla wykonania analiz ilościowych była liczba publikacji naukowych poświęconych ANN znaleziona w bazie Web of Science - dokumenty opublikowane do roku 2015. Badania nad zastosowaniami sztucznych sieci neuronowych w obszarze badawczym rolnictwo rozszerzają się systematycznie. O ciągłym wzroście zainteresowania naukowców możliwościami wykorzystania ANN świadczy również gwałtownie wzrastająca liczba cytowań. Analiza ilościowa publikacji naukowych w 5 wybranych czasopismach naukowych tematycznie związanych z inżynierią rolniczą (indeksowanych w bazie Web of Science) pozwoliła stwierdzić, że 236 artykułów naukowych z lat 1996-2015 było powiązane tematycznie z zastosowaniem ANN. Najwięcej publikacji odnotowano w czasopiśmie Computers and Electronics in Agriculture - 118 artykułów. W latach 2011-2015 występuje tendencja wzrostowa dynamiki publikowania prac naukowych poświęconych zastosowaniom ANN w inżynierii rolniczej. Można zatem wnioskować, że badania związane $\mathrm{z}$ zastosowaniem sztucznych sieci neuronowych w dyscyplinie inżynieria rolnicza będą kontynuowane, a ich zakres i liczba będzie się w dalszym ciągu zwiększać. Analiza tematyki najczęściej cytowanych publikacji z lat 2011-2015 w czasopiśmie Computers and Electronics in Agriculture wykazała, że dotyczą one zarówno zagadnień związanych z problemem klasyfikacji, jak i modelowania procesów i systemów. Należy przypuszczać, że tematyka związana z modelowaniem procesów suszarniczych oraz wykorzystaniem sieci neuronowych do analizy obrazu będzie się w kolejnych latach gwałtownie rozwijać.

Słowa kluczowe: inżynieria rolnicza, sztuczna sieć neuronowa, analiza bibliometryczna, dynamika publikowania 